\title{
Characterization and sensory preference of fermented dairy beverages prepared with different concentrations of whey and araticum pulp
}

\section{Caracterização e preferência sensorial de bebida láctea fermentada elaborada com diferentes concentrações de soro lácteo e polpa de araticum}

\author{
Alexsandra Valéria Sousa Costa de Lima ${ }^{*}$; Edmar Soares Nicolau ${ }^{2}$; \\ Cíntia Silva Minafra e Rezende²; Maria Célia Lopes Torres²; \\ Lorena Gouvêa Novais ${ }^{3}$; Nayana Ribeiro Soares ${ }^{4}$
}

\begin{abstract}
The objective of this study was to develop a fermented dairy beverage flavored with araticum pulp, assess its physicochemical characteristics, microbiological quality, and sensory preference by the consumer. Araticum pulp was prepared using two different methods: with or without bleaching (50 ${ }^{\circ} \mathrm{C} / 5$ minutes). Formulations of fermented dairy beverages consisting of whey (50\%), standardized pasteurized milk (50\%), and seven different concentrations of bleached araticum pulp (5.0, 7.5, 10.0, $12.5,15.0,17.5$, and $20.0 \% \mathrm{w} / \mathrm{v})$ were prepared. In addition, seven formulations of fermented dairy beverage, without adding araticum pulp, and consisting of varying proportions of whey $(40,50,60,70$, 80,90 , and $100 \%$ ) were developed. In all formulations, thickeners/stabilizers were added. All araticum pulp samples (with and without bleach) and fermented dairy beverages (with and without araticum pulp) were analyzed for the relevant physicochemical properties: $\mathrm{pH}$, titratable acidity, acidity of pulp, acidity of fermented beverage, moisture, ash, fat, protein, crude fiber, ascorbic acid, carbohydrates, total solids, and caloric values. Microbiological counts of coliforms at $35^{\circ} \mathrm{C}$ and $45^{\circ} \mathrm{C}$ in the pulp and beverage, and molds and yeasts and Salmonella sp. in the pulp were obtained. Additionally, sensory analysis regarding preferences of the different fermented dairy beverage formulations was also performed. The araticum pulp samples without bleach, showed higher values of $\mathrm{pH}$, moisture, protein, total fiber, and ascorbic acid, as compared to bleached pulp samples, while bleached araticum pulp showed higher values for other physicochemical parameters. Microbiological results showed that all pulps and fruitdairy beverages were suitable for consumption. It was found that there was no significant consumer preference between different fermented beverage formulations, according to the different percentages of pulp. However, the formulations consisting of $40,50,60$, and $70 \%$ whey were preferred over the one consisting of $100 \%$ whey.
\end{abstract}

Key words: Agroindustrial waste. Annona crassiflora. Consumers. Native fruits. Quality.

\footnotetext{
${ }^{1}$ Profa, Instituto Federal Goiano Campus Ceres, IF Goiano, Ceres, GO, Brasil. E-mail: alexsandra.costa@ifgoiano.edu.br

2 Profs., Escola de Veterinária e Zootecnia, Escola de Veterinária e Zootecnia, Escola de Agronomia, Universidade Federal de Goiás, UFG, Goiânia, GO, Brasil. E-mail: rena@cpa.evz.ufg.br; cintiaminafra@gmail.com; celialopes.ufg@gmail.com

${ }^{3}$ Discente do Curso de Medicina Veterinária, Escola de Veterinária e Zootecnia, UFG, Goiânia, GO, Brasil. E-mail: lorenanovais@ hotmail.com

${ }^{4}$ Profa, Instituto Federal do Pará, Campus Marabá Rural, IFPA, Marabá, PA, Brasil. E-mail: nayana.ea@hotmail.com

* Author for correspondence
} 


\section{Resumo}

Objetivou-se com o presente estudo desenvolver uma bebida láctea fermentada saborizada com polpa de araticum, avaliar suas características físico-químicas, qualidade microbiológica e preferência sensorial pelo consumidor. Foram realizados dois modos de preparo da polpa de araticum, sem e com branqueamento $\left(50{ }^{\circ} \mathrm{C} / 5\right.$ minutos $)$, para avaliação da qualidade e escolha de uso das mesmas. Foram elaboradas formulações de bebidas lácteas fermentadas constituídas de soro de leite (50\%), leite pasteurizado padronizado $(50 \%)$ adicionadas de sete concentrações de polpa de araticum branqueada $(\% \mathrm{~m} / \mathrm{v}): 5,0 \% ; 7,5 \% ; 10,0 \% ; 12,5 \% ; 15,0 \% ; 17,5 \%$ e $20,0 \%$. Foram desenvolvidas, também, sete formulações de bebida láctea fermentada, sem adição de polpa, constituídas de soro de leite nas proporções de $40 \% ; 50 \% ; 60 \% ; 70 \% ; 80 \% ; 90 \%$ e $100 \%$, e leite pasteurizado padronizado necessário para completar $100 \%$ da mistura (soro:leite). Em todas as formulações foram adicionados espessantes/ estabilizantes (mistura de $0,25 \%$ de gelatina incolor sem sabor, $0,12 \%$ de proteína láctea e $0,13 \%$ de concentrado protéico de soro) em $0,5 \% \mathrm{~m} / \mathrm{v}$, sacarose $(10 \% \mathrm{~m} / \mathrm{v})$, cultura lática (recomendação do fabricante). Nas amostras de polpa de araticum (sem e com branqueamento) e bebidas lácteas fermentadas (sem e com polpa de araticum) foram realizadas as análises físico-químicas de $\mathrm{pH}$, acidez titulável, acidez em ácido cítrico (na polpa), acidez em ácido lático (na bebida), umidade, cinzas, lipídios, proteínas, fibra bruta (na polpa), ácido ascórbico (na polpa), carboidratos, sólidos totais e valor calórico; avaliações microbiológicas de coliformes a $35^{\circ} \mathrm{C}$ e a $45^{\circ} \mathrm{C}$ (na polpa e bebida), bolores e leveduras e Salmonella sp. (na polpa); além das análises sensoriais de preferência entre as formulações de bebida láctea fermentada. As amostras de polpa de araticum, sem branqueamento, para os parâmetros de $\mathrm{pH}$, umidade, proteína, fibra total e ácido ascórbico apresentaram resultados superiores quando comparadas com as amostras de polpa branqueadas, enquanto para os demais parâmetros físico-químicos foram as amostras de polpa de araticum branqueadas que apresentaram os maiores resultados. Conforme os resultados microbiológicos apresentados todas as amostras de polpas de frutas e as formulações de bebidas lácteas estavam adequadas para o consumo. Constatou-se que não houve preferência significativa entre as formulações de bebida láctea em função dos diferentes percentuais de polpa, todas foram igualmente preferidas pelos consumidores. Entretanto quanto ao percentual de soro presente observou-se que as formulações com 40,50,60 e 70\% foram as mais preferidas quando comparadas com a formulação com $100 \%$.

Palavras-chave: Annona crassiflora. Consumidores. Frutas nativas. Qualidade. Resíduos agroindustriais.

\section{Introduction}

The food industry is striving to offer new and innovative products with the objective of satisfying consumer needs. The growing demand for healthy products has challenged the food and beverage sector (MOREIRA et al., 2010). The development of new products is also considered of great importance, since the diet-health relation represents a challenge for food science and technology, especially in case of functional foods (SOARES et al., 2011). Increasing consumer interest in healthy foods has necessitated the development of innovative food products and creation of new market niches. However, sensory characteristics and specific eating habits of the population must be investigated because they may impede introduction of new foods in the usual diet (JAEKEL et al., 2010).
In biotechnological processes, some alternative sources have been suggested, aiming mainly to optimize the use of industrial waste and reduction in production costs. The incorporation of whey, a by-product from cheese production, is an alternative for use in the dairy industry, and has attracted the interest of many researchers because of its nutritional, functional, and economical potential. The daily production of whey has reached high levels, and its use would minimize its disposal in watercourses, thus reducing further environmental impact (ANTUNES et al., 2004; CIABOTTI1 et al., 2009; CUNHA et al., 2008; GHALY; KAMAL, 2004). While there are a number of technological developments for transformation of whey into other useful products, the use or disposal of whey is still one of the major problems encountered in the dairy 
industry (FERCHICHI et al., 2005; LIRA et al., 2009; PANESAR et al., 2007; PORTO et al., 2005).

Whey is a raw material used in the preparation of new products, mainly milk and fruit-based beverages (COSTA et al., 2007). It has been observed that, while in developed countries approximately $95 \%$ of the total whey is used in the food industry, in Brazil, only $50 \%$ of whey is used (CASTRO et al., 2009). In order to meet the consumer needs, it is necessary to develop dietary products with sensory characteristics similar to the original product. The evaluation of sensory properties of new products is extremely important, as it enables us to identify the effects of product variables on their sensory characteristics (LOURES et al., 2010; MONTANUCI et al., 2010).

Whey products are suitable for all dairy product formulations due to their functional properties, such as gel forming capacity, viscosity, emulsifying power, water retention capacity, providing a series of structural and nutritional benefits to the final product (BELLARDE, 2006). According to Capitani et al. (2005), in Brazil, production of dairy beverages is one of the main options for the use of whey. A recent survey indicates that fermented dairy beverages represent $25 \%$ of the fermented milk market in Brazil (PFLANZER et al., 2010). The demand from Brazilian consumers for healthy, innovative, safe, and practical products, together with the consolidation of the products on the market, contributed to the growth and innovation of dairy beverage industry (THAMER; PENNA, 2006). Beverages based on fruits and milk derivatives are currently receiving considerable attention due to the growth potential of its market, because of their pleasant sensory properties and high nutritional value (ZULUETA et al., 2007).

The Brazilian cerrado biome, typical of the tropical zone, is a formation of savannah that covers approximately 2.0 million $\mathrm{km}^{2}$ and corresponds to $23.1 \%$ of the Brazilian territory. It has a large number of native and exotic fruit species that are under-exploited, of potential interest to the agricultural industry, and a possible future source of income for the local population (ALMEIDA et al., 2011; LUZIA; JORGE, 2013). The interest in native flora of South America has been growing in recent years due to its health benefits. Brazil has more than 40,000 different plant species representing $20 \%$ of the world's flora. Several of the registered species have potential as a functional food in laboratory studies. Other species are unknown or have not yet been subjected to any study of their health benefits (OLIVEIRA et al., 2012). Among these, araticum (Annona crassiflora Mart.) is of particular interest because it produces large fruits with characteristic smell and flavor, appreciated by the local population, making them of great value for commercialization (LUZIA; JORGE, 2013; MESQUITA et al., 2007).

Information regarding the chemical composition and nutritional value of the cerrado fruits are basic tools for evaluating consumption and formulation of new products. However, few data are available in the specialized literature regarding the chemical composition of these fruits and their technological applications, emphasizing the need for scientific research on the subject (SILVA et al., 2008). Brazil is one of the three major producers of fruit throughout the world. Native and/or exotic Brazilian fruits have high nutritional and economic potential, but these seasonal fruits have high post-harvest losses. Thus, it is necessary to start competitive agrobusinesses in production regions of these fruits to improve local economies (CLERICI; CARVALHO-SILVA, 2011).

The use of regional fruits, with characteristic flavors in the production of new products, is an alternative to their best use. The commercialization of fruits is restricted to their harvest season, and their high perishability necessitates viable product development (ANSELMO et al., 2006). The formulation of a fermented dairy beverage using whey is presented as a contribution to minimizing the environmental problem, caused by the disposal of this effluent. This fact, combined with the associated nutritious value of araticum and whey, 
in addition to the use of bacteria with probiotic potential, will result in the development of a final product with functional characteristics (MENEZES, 2011). Most of the available dairy products use flavors derived from fruits of temperate climate: strawberry, plum, or peach. However, Brazil offers a range of fruits with different flavors and aromas, which may provide an alternative in the production of dairy products (BORGES et al., 2009).

The objective of this work was to develop a fermented milk beverage flavored with araticum pulp, evaluating its physicochemical characteristics, microbiological quality, and sensory preference by the consumer.

\section{Material and Methods}

\section{Location}

The research was conducted at the Food Research Center at the Veterinary and Animal Handling School in the Department of Food Engineering of the Agronomy and Food Engineering School, and in the Food Quality Control Laboratory of the Pharmacy School in the Federal University of Goias (UFG).

\section{Raw materials}

The sugar ingredients (brand Cristal Alimentos), araticum fruit, thickeners/stabilizers (brand Casa Forte/Dr. Oetker Powder Tasteless Colorless Gelatin), and standardized pasteurized milk (brand CompLeite) with a fat content of $3 \%$ were obtained from retail market in the city of Goiania, GO. The whey was obtained according to the methodology described by Alves (2010), Hofmeister et al. (2005) and Martins et al. (2012) with some modifications. The protocol followed was as follows: heating of pasteurized whole milk to $35^{\circ} \mathrm{C}$, addition of calcium chloride (50\% solution) and liquid rennet, resting for 50 minutes, coagulation and mass cutoff point test, slowly cutting the mass and getting large cubes (grain no. 1), letting the mass rest for 15 minutes, perform 1 st and 2 nd stirring for 15 minutes slowly and smoothly, syneresis and collection of the whey.

\section{Collection and processing of fruit pulp}

The fruits of araticum (Annona crassiflora Mart) were purchased at street markets in GoiâniaGO. Preselection was followed by prewashing in running water and sanitizing with chlorine solution at a concentration of $200 \mathrm{ppm}$ by immersing for 15 minutes. Further steps included rinsing under running water, selection, and manual peeling. Pulp was made using an electric mixer (brand FAET DULKA) to separate seeds from the pulp. Refining of the araticum pulp was done using a removing device (brand BRAESI DES-60). A part of this refined pulp did not receive bleaching treatment, while another part of the refined pulp underwent bleaching treatment at $50{ }^{\circ} \mathrm{C}$ for 5 minutes. Last step involved filling and manual packaging in bags $(100 \mathrm{~mL})$ and pots $(1 \mathrm{~L})$ of polyethylene, followed by freezing and storage at a temperature of $-25{ }^{\circ} \mathrm{C}$ until the time of their use and analysis. Thus, two types of araticum pulp samples were obtained after the refining and freezing process: non bleached and bleached.

\section{Formulation of fermented dairy beverages}

Fermented dairy beverages were prepared consisting of whey (50\%), standardized pasteurized milk (50\%), thickener/stabilizer (mixture of $0.25 \%$ colorless powdered flavorless gelatin, $0.12 \%$ of dairy protein and $0.13 \%$ of whey protein concentrate) in $0.5 \% \mathrm{w} / \mathrm{v}$, sucrose $(10 \% \mathrm{w} / \mathrm{v})$, lactic culture (manufacturer's recommendation), and different concentrations of bleached araticum pulp. The pulp concentrations $(\% \mathrm{w} / \mathrm{v})$ were as follows: (T1) $5.0 \%$, (T2) 7.5\%, (T3) $10.0 \%$, (T4) $12.5 \%$, (T5) $15.0 \%$, (T6) $17.5 \%$, and (T7) $20.0 \%$, relative to the volume of the beverage. Fermented dairy beverage formulations were also developed, 
without adding the araticum pulp, consisting of thickener/stabilizer (mixture of $0.25 \%$ gelatin, $0.12 \%$ dairy protein and $0.13 \%$ of whey protein concentrate) in $0.5 \% \mathrm{w} / \mathrm{v}$; sucrose $(10 \% \mathrm{w} / \mathrm{v})$, lactic culture (manufacturer's recommendation), whey in the proportions of $40 \%$ (T40), 50\% (T50), $60 \%$ (T60), 70\% (T70), 80\% (T80), 90\% (T90), and $100 \%$ (T100), and standardized pasteurized milk necessary to complete $100 \%$ of the mixture (whey: milk). Flavoring agents, dyes, or preservatives were added to the formulations.

\section{Preparation of the fermented dairy beverages}

The processing of fermented dairy beverages was based on the methodology described by Santos et al. (2008) with some modifications. Sucrose and thickeners/stabilizers were added to the mixture of milk and whey, and this mixture was pasteurized at $65{ }^{\circ} \mathrm{C}$ for 30 minutes, and cooled to $43{ }^{\circ} \mathrm{C}$. Then, lactic culture, directly inoculated with $\mathrm{Sacco}{ }^{\circledR}$ Lyofast Y450, consisting of strains of Streptococcus salivarius ssp. thermophilus and Lactobacillus delbrueckii ssp. bulgaricus, was added to the mixture. Homogenization and incubation were performed at $43{ }^{\circ} \mathrm{C}$ for an average period of five hours. The fermentation of the dairy beverage occurred until the medium $\mathrm{pH}$ reached a value of $4.3 \pm 0.25$. This $\mathrm{pH}$ range was determined according to the sensory and preservation characteristics of the product, after conducting preliminary tests and review regarding the subject. After fermentation, the dairy beverage was kept under refrigeration at a temperature of $4 \pm 1{ }^{\circ} \mathrm{C}$ for 12 hours, the clot being broken by manual agitation at the end of that period. After breaking the clot, the araticum pulp was added (in the formulations with fruit pulp) and homogenized. The final beverages were filled in transparent polyethylene bottles (1 L and $140 \mathrm{~mL}$ ) and stored at $4 \pm 1{ }^{\circ} \mathrm{C}$ until the time of performing the analysis.
Chemical composition and physicochemical properties of araticum pulp frozen with and without bleaching

Frozen araticum pulp samples, with and without bleaching, were analyzed for their physicochemical properties: moisture $(\% \mathrm{~m} / \mathrm{m})$, ashes $(\% \mathrm{~m} / \mathrm{m})$, lipids $(\% \mathrm{w} / \mathrm{w})$, total protein $(\% \mathrm{~m} / \mathrm{m})$, crude fiber (g/100g), ascorbic acid/vitamin C (mg/100g), pH, titratable acidity $(\mathrm{g} / 100 \mathrm{~g})$, and acidity in citric acid $(\mathrm{g} / 100 \mathrm{~g})$, according to procedures from IAL (2008). The values of total solids were obtained from the difference between total sample weight and moisture content of the same (CECCHI, 2007). The percentage of carbohydrates was calculated per difference, where the total carbohydrates were equal to the amount of moisture, ashes, proteins, and lipids subtracted from one hundred (SOARES JUNIOR et al., 2010). The calculation of total energy from the nutrients was expressed in kilocalories (kcal), estimated from the Atwater conversion factors: kcal $=(4 \times \mathrm{g}$ protein $)+(4 \times \mathrm{g}$ carbohydrate $)+(9 \times \mathrm{g}$ lipid) (TACO, 2011).

\section{Chemical composition and physicochemical properties of fermented dairy beverages}

The moisture percentage was determined by a gravimetric method, by heating at $105{ }^{\circ} \mathrm{C}$. The ash percentage was determined gravimetrically by incineration in a muffle furnace at $550{ }^{\circ} \mathrm{C}$. The lipid content was measured gravimetrically after extraction in Mojonnier bottles. The total protein content was determined by the micro-Kjeldahl method, using nitrogen for protein conversion factor (6.38). The $\mathrm{pH}$ was determined using a previously calibrated potentiometer. The percentage of titratable acidity was determined by titrating the sample, and the results were expressed as a percentage of lactic acid. The physicochemical analysis of moisture, ashes, lipids, total protein, $\mathrm{pH}$, and titratable acidity were determined according to Brasil (2006). The total solids were obtained from the difference between the total sample weight and the wet basis 
moisture content of the same (CECCHI, 2007). The percentage of carbohydrates was calculated per difference, where the total carbohydrates are equal to the amount of moisture, ashes, proteins, and lipids subtracted from one hundred (SOARES JUNIOR et al., 2010). The calculation of the total energy from the nutrients was expressed in kilocalories (kcal), estimated from the Atwater conversion factors: $\mathrm{kcal}$ $=(4 \times \mathrm{g}$ protein $)+(4 \times \mathrm{g}$ carbohydrate $)+(9 \times \mathrm{g}$ lipid) (TACO, 2011).

\section{Microbiological evaluation of frozen araticum pulp}

The microbiological count in araticum pulp was evaluated from the Most Probable Number/ $\mathrm{mL}(\mathrm{MPN} / \mathrm{mL})$ of total coliforms $\left(35^{\circ} \mathrm{C}\right)$ and thermotolerant coliforms $\left(45^{\circ} \mathrm{C}\right)$, mold and yeast count, and presence of Salmonella sp. (DOWNES; ITO, 2001), according to microbiological parameters established by the legislation for fruit pulp (BRASIL, 2000, 2001). All experiments were performed in triplicate.

\section{Microbiological evaluation of the fermented dairy beverages}

The microbiological tests were performed, according to the method described by Brasil (2003). The method evaluated presence of total coliforms $\left(35^{\circ} \mathrm{C}\right)$ and thermotolerant coliforms (45 ${ }^{\circ} \mathrm{C}$ ), according to the microbiological parameters established by the legislation for fermented dairy beverages (BRASIL, 2005). All experiments were performed in triplicate.

\section{Sensory analysis of the fermented dairy beverages}

The formulations of fermented dairy beverages were analyzed from a preference test, in which fifty non-trained tasters evaluated the samples. Each tester was offered seven samples, packed in disposable white plastic cups $(50 \mathrm{~mL})$, properly coded with three-digit numbers, using Friedman test (Newell and Mac Farlane Table), according to Minim (2010). The samples were served in individual booths, illuminated with white light, and the tasters ordered the samples in ascending order of preference: assigning 1 for the least preferred sample to 7 for the most preferred one. The environmental procedures and conditions of the sensory analysis are in agreement with the recommendations of Minim (2010). The project was approved by the Comitê de Ética em Pesquisa/UFG, Protocol No. 038/12.

\section{Statistical analysis}

The results from physicochemical experiments were analyzed using ANOVA test, and the differences of averages were compared by Tukey test at 5\% of significance level. The results of the microbiological analysis were evaluated descriptively. The results of the ordering-preference analysis were analyzed using the Friedman test (Newell and Mac Farlane Table), according to Minim (2010). All physicochemical and microbiological determinations, in the samples were performed in triplicate. Statistical tests were conducted using the R software version 2.11.1 (R DEVELOPMENT CORE TEAM, 2010).

\section{Results and Discussion}

\section{Physicochemical analysis of frozen araticum pulp}

Theresults of the physicochemical determinations of the araticum pulp with and without bleaching are shown in Table 1. It was observed that the values of $\mathrm{pH}$, moisture, protein, crude fiber, and ascorbic acid were higher $(p<0.05)$ in samples without bleaching pulp compared to those observed in bleached pulp, whereas the values of ashes, lipids, total acidity, acidity in citric acid, total solids, total carbohydrates and caloric values of bleached pulp were higher $(p<0.05)$ than those without bleaching pulp. During the bleaching process, the moisture and protein content of pulp samples reduced due to the applied heat treatment, the interference in the protein content 
probably causing protein denaturation. The content of crude fiber and ascorbic acid will also suffer similar reduction. On the contrary, the application of bleaching increased the amounts of ashes, lipids, total solids, total carbohydrates, and caloric values, due to the process of heat-based concentration of the samples.

Table 1. Determination of $\mathrm{pH}$, moisture, protein, crude fiber, ascorbic acid, ashes, lipids, total acidity, acidity in citric acid, total solids, total carbohydrate, and caloric values from araticum pulp samples.

\begin{tabular}{ccc}
\hline Characteristics & Araticum Pulp without bleaching & Bleached araticum pulp \\
\hline pH & $4.86 \pm 0.01 \mathrm{a}$ & $4.59 \pm 0.01 \mathrm{~b}$ \\
Moisture (\%) & $72.85 \pm 0.05 \mathrm{a}$ & $70.46 \pm 0.43 \mathrm{~b}$ \\
Proteins (\%) & $1.93 \pm 0.01 \mathrm{a}$ & $1.64 \pm 0.07 \mathrm{~b}$ \\
Crude Fiber (\%) & $2.35 \pm 0.09 \mathrm{a}$ & $1.96 \pm 0.16 \mathrm{~b}$ \\
Ascorbic Acid (\%) & $2.23 \pm 0.11 \mathrm{a}$ & $1.75 \pm 0.01 \mathrm{~b}$ \\
Ashes (\%) & $0.56 \pm 0.03 \mathrm{~b}$ & $0.79 \pm 0.02 \mathrm{a}$ \\
Lipids (\%) & $2.57 \pm 0.18 \mathrm{~b}$ & $3.92 \pm 0.03 \mathrm{a}$ \\
Titratable Total Acidity (\%) & $7.77 \pm 0.06 \mathrm{~b}$ & $8.61 \pm 0.01 \mathrm{a}$ \\
Acidity in Citric Acid (\%) & $0.50 \pm 0.01 \mathrm{~b}$ & $0.55 \pm 0.00 \mathrm{a}$ \\
Total Solids (\%) & $27.15 \pm 0.05 \mathrm{~b}$ & $29.54 \pm 0.43 \mathrm{a}$ \\
Total Carbohydrates (\%) & $19,74 \pm 0,16 \mathrm{~b}$ & $21,22 \pm 0,59 \mathrm{a}$ \\
Caloric Value (kcal) & $109,84 \pm 1,04 \mathrm{~b}$ & $126,76 \pm 2,10 \mathrm{a}$ \\
\hline
\end{tabular}

The values correspond to the average of three repetitions with standard deviation estimate. Averages followed by different letters in the line differ from each other $(\mathrm{p}<0.05)$.

The study of Silva et al. (2008), which also analyzed the composition of the araticum fruits, showed lower total energy value $(90.47 \mathrm{kcal})$, proteins $(1.22 \pm 0.04 \%)$, and carbohydrates $(12.78$ $\pm 0.67 \%)$, and higher values of humidity $(76.05$ $\pm 0.16 \%)$, fiber $(4.72 \pm 0.55 \%)$, and ash $(1.37 \pm$ $0.01 \%$ ), as compared to those observed in this study (Table 1). Souza et al. (2012) found higher moisture content $(80.16 \pm 0.25 \%)$ and ascorbic acid (59.05 $\pm 0.46 \%$ ) in araticum pulps, while the content of lipids (1.84 $\pm 0.16 \%$ ), carbohydrates (16.31 $\pm 0.26 \%)$, energy $(85.47 \pm 0.11 \mathrm{kcal})$, fiber $(0.13$ $\pm 0.00 \%)$, proteins $(0.92 \pm 0.02 \%)$, and $\mathrm{pH}(4.44$ $\pm 0.04)$ were lower than from this research. The differences in relation to physicochemical analysis of fruits samples and pulps of araticum fruit can be associated with geographic locations of harvest and varying degrees of ripeness.
Microbiological evaluation of frozen araticum pulp samples

Microbiological evaluation of araticum pulp samples with and without bleaching showed results withinthe standards required by legislation(BRASIL, $2000)$, with respect to coliform counts at $35^{\circ} \mathrm{C}$ and $(<0.3)$ and $45^{\circ} \mathrm{C}(<0.3)$, molds and yeasts $\left(4.2 \times 10^{2}\right.$ $\mathrm{CFU} / \mathrm{mL}$ and $<1.0 \mathrm{CFU} / \mathrm{mL}$ ), and Salmonella sp. (absence). These results demonstrated adequate sanitary conditions during the entire process of collecting and processing of pulp samples. It was observed that the bleaching process carried out on araticum pulp samples led to a great reduction in the number of mold and yeast colonies $(<1.0 \mathrm{CFU} /$ $\mathrm{mL}$ ), as compared with the without bleaching pulp samples $\left(4.2 \times 10^{2} \mathrm{CFU} / \mathrm{mL}\right)$. According to Bueno et al. (2002), low microbial count in the pulps can be attributed to the good quality of the raw material used in the product manufacture, in addition to the destruction of microorganisms promoted by subsequent bleaching, cooling, and freezing. 
Physicochemical characterization of different fermented milk beverages prepared with different concentrations of araticum pulp

The fermented dairy beverage formulations (Table 2) were similar in terms of the following parameters: acidity in lactic acid (0.59 to $0.61 \%)$, $\mathrm{pH}$ (4.24 to 4.33), and total carbohydrates (13.45 to $13.73 \%$ ). Oliveira et al. (2008) obtained similar $\mathrm{pH}$ values in yoghurt samples consisting of 0.00 to $25 \%$ araticum pulp, as those in our experiments. However, higher acidity values of lactic acid between 0.70 and $0.79 \%$ were observed in their experiments. T5, T6, and $\mathrm{T} 7$ formulations showed the highest percentage of ashes $(0.54,0.59$, and $0.63 \%)$, lipids $(2.20,2.27$, and $2.40 \%)$ and proteins $(2.99,3.11$, and $3.18 \%)$, were similar, but differed significantly $(\mathrm{p}<0.05)$ from T1 formulation (Table 2 and 3) that had the lowest percentage of ashes $(0.40 \%)$, lipids $(1.83 \%)$, and proteins $(2.53 \%)$.

Table 2. Determination of acidity in lactic acid, $\mathrm{pH}$, total solids, total carbohydrates, and caloric values from the samples of fermented dairy beverages prepared with different araticum pulp concentrations.

\begin{tabular}{ccclll}
\hline \multicolumn{5}{c}{ Characteristics } \\
\hline Treatments & Acidity $(\%)$ & $\mathrm{pH}$ & \multicolumn{1}{c}{ Total Solids $(\%)$} & Total Carbohydrates $(\%)$ & Caloric Value (kcal) \\
\hline T1 & $0.59 \pm 0.00 \mathrm{a}$ & $4.24 \pm 0.04 \mathrm{a}$ & $18.50 \pm 0.10 \mathrm{~b}$ & $13.73 \pm 0.10 \mathrm{a}$ & $85.04 \pm 0.46 \mathrm{c}$ \\
T2 & $0.60 \pm 0.01 \mathrm{a}$ & $4.25 \pm 0.04 \mathrm{a}$ & $18.55 \pm 0.14 \mathrm{ab}$ & $13.45 \pm 0.41 \mathrm{a}$ & $85.58 \pm 0.45 \mathrm{c}$ \\
T3 & $0.60 \pm 0.02 \mathrm{a}$ & $4.25 \pm 0.04 \mathrm{a}$ & $18.84 \pm 0.57 \mathrm{ab}$ & $13.56 \pm 0.77 \mathrm{a}$ & $87.03 \pm 1.94 \mathrm{bc}$ \\
T4 & $0.60 \pm 0.02 \mathrm{a}$ & $4.26 \pm 0.06 \mathrm{a}$ & $19.19 \pm 0.20 \mathrm{ab}$ & $13.72 \pm 0.24 \mathrm{a}$ & $88.61 \pm 0.59 \mathrm{abc}$ \\
T5 & $0.60 \pm 0.03 \mathrm{a}$ & $4.28 \pm 0.03 \mathrm{a}$ & $19.31 \pm 068 \mathrm{ab}$ & $13.58 \pm 0.88 \mathrm{a}$ & $90.04 \pm 1.72 \mathrm{ab}$ \\
T6 & $0.61 \pm 0.01 \mathrm{a}$ & $4.28 \pm 0.01 \mathrm{a}$ & $19.44 \pm 0.65 \mathrm{ab}$ & $13.47 \pm 0.70 \mathrm{a}$ & $90.94 \pm 2.25 \mathrm{a}$ \\
T7 & $0.61 \pm 0.03 \mathrm{a}$ & $4.33 \pm 0.04 \mathrm{a}$ & $19.73 \pm 0.09 \mathrm{a}$ & $13.53 \pm 0.29 \mathrm{a}$ & $92.31 \pm 0.27 \mathrm{a}$ \\
\hline
\end{tabular}

Legend: T1: 5.0\%, T2: 7.5\%, T3: 10.0\%, T4: 12.5\%, T5: 15.0\%, T6: 17.5\%, and T7: 20.0\% of pulp.

Averages in the same column and with the same letters do not differ significantly from each other by Tukey test $(\mathrm{p}<0.05)$. The values correspond to the average of three repetitions with standard deviation estimate.

The T1 formulation showed significantly $(\mathrm{p}<0.05)$ lower content of total solids $(18.50 \%)$ and higher moisture content $(81.50 \%)$, as compared to T7 formulation, while the other formulations showed similar values for these properties (Table 2 and 3). The formulations with T1, T2, and T3 showed the lowest caloric values, and differed significantly $(p<0.05)$ from T6 and T7 formulations, which showed the highest values (Table 2). The protein values (Table 3), regardless of the formulation, were above the minimum content $(1.0 \%)$ required by legislation (BRASIL, 2005). An increasing in pulp percentage showed a reduction in moisture content (Table 3) due to the presence of solids in the pulps, with significant differences between the $\mathrm{T} 1$ and $\mathrm{T} 7$ samples. 
Table 3. Determination of moisture, ashes, lipids, and proteins from samples of fermented dairy beverages prepared with different concentrations of araticum pulp.

\begin{tabular}{cllll}
\hline \multicolumn{5}{c}{ Characteristics } \\
\hline Treatments & \multicolumn{1}{c}{ Moisture (\%) } & \multicolumn{1}{c}{ Ashes $(\%)$} & \multicolumn{1}{c}{ Lipids (\%) } & \multicolumn{1}{c}{ Proteins (\%) } \\
\hline T1 & $81.50 \pm 0.10 \mathrm{a}$ & $0.40 \pm 0.01 \mathrm{~d}$ & $1.83 \pm 0.12 \mathrm{~d}$ & $2.53 \pm 0.12 \mathrm{~d}$ \\
T2 & $81.45 \pm 0.14 \mathrm{ab}$ & $0.49 \pm 0.04 \mathrm{~cd}$ & $1.93 \pm 0.15 \mathrm{~cd}$ & $2.67 \pm 0.12 \mathrm{~cd}$ \\
T3 & $81.16 \pm 0.57 \mathrm{ab}$ & $0.51 \pm 0.02 \mathrm{bc}$ & $2.03 \pm 0.12 \mathrm{bcd}$ & $2.74 \pm 0.16 \mathrm{~cd}$ \\
T4 & $80.81 \pm 0.20 \mathrm{ab}$ & $0.53 \pm 0.01 \mathrm{bc}$ & $2.13 \pm 0.06 \mathrm{abcd}$ & $2.80 \pm 0.04 \mathrm{bcd}$ \\
T5 & $80.69 \pm 0.68 \mathrm{ab}$ & $0.54 \pm 0.02 \mathrm{abc}$ & $2.20 \pm 0.10 \mathrm{abc}$ & $2.99 \pm 0.21 \mathrm{abc}$ \\
T6 & $80.56 \pm 0.65 \mathrm{ab}$ & $0.59 \pm 0.06 \mathrm{ab}$ & $2.27 \pm 0.15 \mathrm{ab}$ & $3.11 \pm 0.10 \mathrm{ab}$ \\
T7 & $80.27 \pm 0.09 \mathrm{~b}$ & $0.63 \pm 0.05 \mathrm{a}$ & $2.40 \pm 0.10 \mathrm{a}$ & $3.18 \pm 0.07 \mathrm{a}$ \\
\hline
\end{tabular}

Legend: T1: $5.0 \%$, T2: 7.5\%, T3: 10.0\%, T4: $12.5 \%$, T5: $15.0 \%$, T6: $17.5 \%$, and T7: $20.0 \%$ of pulp.

Averages in the same column and with the same letters do not differ significantly from each other by Tukey test $(\mathrm{p}<0.05)$. The values correspond to the average of three repetitions with standard deviation estimate.

Physicochemical characterizations of fermented dairy beverage samples prepared with different whey concentrations

An increase in the percentage of whey in the different formulations resulted in reducing acidity expressed in lactic acid, resulting in an increased $\mathrm{pH}$. The beverages formulated with $40,50,60$, and $70 \%$ of whey (Table 4 ) showed the significantly higher and lower acidity values and lower $\mathrm{pH}$ values, respectively, as compared to beverages formulated with 80,90 , and $100 \%$ of whey. Andrade (2010), while evaluating different brands of dairy beverage, observed that they showed an average $\mathrm{pH}$ below 4.6, which is the isoelectric point of casein. In this study, $\mathrm{pH}$ values of formulations containing 40 to $90 \%$ of whey (Table 4) were below this value. According to Thamer and Penna (2006), the differences in $\mathrm{pH}$ values in the different products can be influenced by several factors: percentage of whey, activity of lactic culture, $\mathrm{pH}$ value marking end of the fermentation, addition of different ingredients, and storage duration. By checking the $\mathrm{pH}$ of, Almeida et al. (2001) found average $\mathrm{pH}$ values of 4.63, 4.56, and 4.61 for fermented dairy beverages prepared with 30,40 , and $50 \%$ of whey, respectively. These values were higher than the formulations with 40 to $80 \%$ of whey (4.13 to 4.27 ) described in this work (Table 4), since they were measured immediately after fermentation of the dairy beverages. Oliveira et al. (2006) found $\mathrm{pH}$ values of fermented dairy beverages enriched with iron, prepared with concentrations of 10,30 , and $50 \%$ of whey and that are comparable to the values of formulations with 40 to $70 \%$ of whey in this study. The low average $\mathrm{pH}$ values also contribute in inhibiting the growth of undesirable microorganisms in fermented dairy beverages.

There is no established standard for titratable acidity in the Technical Regulation of Identity and Quality (RTIQ) of Dairy Beverage for fermented dairy beverages. However, the titratable acidity values of samples formulated with 40,50 , and $60 \%$ of whey (Table 4 ) are consistent with the RTIQ of Fermented Milks (BRASIL, 2007), which recommends a minimum titratable acidity value of $60^{\circ} \mathrm{D}$. Titratable acidity results similar to those from formulations of 40 to $70 \%$ of whey ( 0.64 to 0.53 $\mathrm{g} / 100 \mathrm{~g}$ of lactic acid) were obtained by Almeida et al. (2001) in fermented dairy beverages prepared with yogurt culture prepared with 30,40 , and $50 \%$ of whey stored for 28 days ( 0.54 to $0.66 \%$ ).

The total carbohydrate content (13.71 to $14.20 \%$ ), it was observed that all formulations of fermented dairy beverage were significantly $(p<0.05)$ equal from each other (Table 4). 
Table 4. Determination of acidity in lactic acid, $\mathrm{pH}$, total solids, total carbohydrates, and caloric value from samples of fermented dairy beverages prepared with different concentrations of whey.

\begin{tabular}{ccccll}
\hline \multicolumn{5}{c}{ Characteristics } \\
\hline Treatments & Acidity $(\%)$ & $\mathrm{pH}$ & \multicolumn{1}{c}{ Total Solids $(\%)$} & Total Carbohydrates $(\%)$ & Caloric Value (kcal) \\
\hline T40 & $0.64 \pm 0.00 \mathrm{a}$ & $4.13 \pm 0.01 \mathrm{f}$ & $19.14 \pm 0.03 \mathrm{a}$ & $13.71 \pm 0.19 \mathrm{a}$ & $83.79 \pm 0.42 \mathrm{a}$ \\
T50 & $0.63 \pm 0.00 \mathrm{a}$ & $4.18 \pm 0.01 \mathrm{e}$ & $18.63 \pm 0.03 \mathrm{~b}$ & $13.80 \pm 0.18 \mathrm{a}$ & $80.65 \pm 0.29 \mathrm{~b}$ \\
T60 & $0.56 \pm 0.02 \mathrm{~b}$ & $4.21 \pm 0.01 \mathrm{de}$ & $18.34 \pm 0.09 \mathrm{c}$ & $13.83 \pm 0.14 \mathrm{a}$ & $78.15 \pm 0.81 \mathrm{c}$ \\
T70 & $0.53 \pm 0.00 \mathrm{~b}$ & $4.23 \pm 0.01 \mathrm{~d}$ & $17.78 \pm 0.24 \mathrm{~d}$ & $14.17 \pm 0.21 \mathrm{a}$ & $74.71 \pm 1.32 \mathrm{~d}$ \\
T80 & $0.47 \pm 0.00 \mathrm{c}$ & $4.27 \pm 0.02 \mathrm{c}$ & $17.10 \pm 0.04 \mathrm{e}$ & $14.04 \pm 0.26 \mathrm{a}$ & $70.59 \pm 0.80 \mathrm{e}$ \\
T90 & $0.32 \pm 0.00 \mathrm{~d}$ & $4.56 \pm 0.01 \mathrm{~b}$ & $16.76 \pm 0.04 \mathrm{f}$ & $14.08 \pm 0.18 \mathrm{a}$ & $67.91 \pm 0.38 \mathrm{f}$ \\
T100 & $0.22 \pm 0.00 \mathrm{e}$ & $4.88 \pm 0.01 \mathrm{a}$ & $16.23 \pm 0.05 \mathrm{~g}$ & $14.20 \pm 0.09 \mathrm{a}$ & $64.13 \pm 0.38 \mathrm{~g}$ \\
\hline
\end{tabular}

Legend: T40: 40\%, T50: 50\%, T60: 60\%, T70: 70\%, T80: 80\%, T90: 90\%, T100: $100 \%$ of whey.

Averages in the same column and with the same letters do not differ significantly from each other by Tukey test $(\mathrm{p}<0.05)$. The values correspond to the average of three repetitions with standard deviation estimate.

The moisture percentage (Table 5) increased with an increase in whey concentration in the different formulations of dairy beverages, while there was a reduction in total solids content and caloric values (Table 4). All formulations differed significantly $(p<0.05)$ in their moisture contents, total solids contents, and caloric values (Tables 4 and 5). The replacement of part of the quantity of milk (40 to $100 \%$ ) by whey also contributed to obtain a product with a lower caloric value ( 83.79 to $64.13 \%$ ). The addition of whey resulted in products with lower contents of total solids (19.14 to $16.23 \%$ ), proteins (2.97 to $1.38 \%$ ), lipids ( 1.90 to $0.20 \%$ ), and caloric value ( 83.79 to $64.13 \%$ ) (Tables 4 and 5). The RTIQ of Dairy Beverage (BRASIL, 2005) does not define criteria for the percentage of moisture content and total dry extract. The values of total solids and moisture content from the formulations of 40 to $90 \%$ whey (Table 4) are consistent with those described by Andrade (2010) for dairy beverage. The moisture values found for dairy beverage samples (Table 5) are lower, while the values found for total solids are higher, than those found for milk. This is explained by the additives (sugars and thickeners) used in the technology of production of dairy drinks, which cause an increase in the total solids content and decrease in the moisture content of these products.

With the increase in the percentage of whey in the formulations (Table 5), there was a reduction in the percentage of ashes, lipids, and proteins. Almeida et al. (2001) found a 1.92, 1.76, and 1.59 reduction in the percentage of fat in fermented dairy beverages with 30,40 , and 50 of whey, respectively, consistent with results in our study. Oliveira et al. (2006) showed a reduction of 2.6, 2.0, and $16 \%$ in the fat percentages of fermented dairy beverages enriched with iron and consisting of 10, 30, and $50 \%$ of whey, respectively. The addition of whey in dairy beverages can help in the acceptance of dairy beverage because according to Andrade (2010) many consumers prefer healthy food with reduced fat.

The protein values in the formulations with 40 and $50 \%$ whey were higher than those found by Almeida et al. (2001). Thamer and Penna (2006), found protein content of probiotic dairy beverages of different formulations ranging between 1.93 and $2.46 \%$, and Oliveira et al. (2006) found protein content values of fermented dairy beverages enriched with iron and consisting of different whey concentrations between 1.65 and $2.08 \%$. The protein content values (Table 5) observed for formulations with 60 to $80 \%$ of whey in this study were similar to the values reported in previous studies. The minimum standard for protein established in RTIQ of Dairy Beverages (BRASIL, 2005) is of $1.7 \%$ for fermented dairy beverages without additions, $1.4 \%$ for fermented dairy beverages with 
fermented milk(s) added, and $1.0 \%$ for fermented dairy beverages with additions or fermented dairy beverage with product(s) or food substance(s). The amounts of protein, regardless of the formulation, were above the minimum content $(1.0 \%)$ required by the legislation (BRASIL, 2005).
The lipid and protein content of formulations with 40 to $70 \%$ of whey showed the highest percentages, and were significantly $(\mathrm{p}<0.05)$ different from formulations with 80 to $100 \%$ with lower values of lipids and proteins.

Table 5. Determination of moisture, ashes, lipids, and proteins from samples of fermented dairy beverages prepared with different concentrations of whey.

\begin{tabular}{ccccc}
\hline \multicolumn{5}{c}{ Characteristics } \\
\hline Treatments & Moisture (\%) & Ashes (\%) & Lipids (\%) & Proteins (\%) \\
\hline T40 & $80.86 \pm 0.03 \mathrm{~g}$ & $0.56 \pm 0.02 \mathrm{a}$ & $1.90 \pm 0.10 \mathrm{a}$ & $2.97 \pm 0.07 \mathrm{a}$ \\
T50 & $81.37 \pm 0.03 \mathrm{f}$ & $0.55 \pm 0.03 \mathrm{a}$ & $1.67 \pm 0.06 \mathrm{ab}$ & $2.61 \pm 0.13 \mathrm{~b}$ \\
T60 & $81.66 \pm 0.09 \mathrm{e}$ & $0.55 \pm 0.00 \mathrm{a}$ & $1.40 \pm 0.10 \mathrm{bc}$ & $2.56 \pm 0.11 \mathrm{~b}$ \\
T70 & $82.22 \pm 0.24 \mathrm{~d}$ & $0.54 \pm 0.03 \mathrm{a}$ & $1.15 \pm 0.05 \mathrm{c}$ & $1.92 \pm 0.01 \mathrm{c}$ \\
T80 & $82.90 \pm 0.04 \mathrm{c}$ & $0.54 \pm 0.02 \mathrm{a}$ & $0.87 \pm 0.15 \mathrm{~d}$ & $1.65 \pm 0.12 \mathrm{~d}$ \\
T90 & $83.24 \pm 0.04 \mathrm{~b}$ & $0.53 \pm 0.03 \mathrm{a}$ & $0.60 \pm 0.10 \mathrm{~d}$ & $1.55 \pm 0.06 \mathrm{de}$ \\
T100 & $83.77 \pm 0.05 \mathrm{a}$ & $0.45 \pm 0.03 \mathrm{~b}$ & $0.20 \pm 0.10 \mathrm{e}$ & $1.38 \pm 0.09 \mathrm{e}$ \\
\hline
\end{tabular}

Legend: T40: 40\%, T50: 50\%, T60: 60\%, T70: 70\%, T80: $80 \%$, T90: 90\%, T100: $100 \%$ of whey.

Averages in the same column and with the same letters do not differ significantly from each other by Tukey test $(p<0.05)$. The values correspond to the average of three repetitions with standard deviation estimate.

Microbiological analysis of the samples offermented dairy beverage prepared with and without araticum pulp

Microbiological analysis performed on all the samples of fermented dairy beverages showed coliform counts at $35^{\circ} \mathrm{C}$ and $45^{\circ} \mathrm{C}$ were both below $0.3 \mathrm{MPN} / \mathrm{mL}$, thus complying with the reference standards of the legislation in force (maximum of $10^{2}$ and $10 \mathrm{MPN} / \mathrm{mL}$ at $35^{\circ} \mathrm{C}$ and $45^{\circ} \mathrm{C}$, respectively) (BRASIL, 2005). Thus, all the formulations were within the microbiological standards established by the legislation in force, indicating sanitary practices and strict quality control during the production of fermented dairy beverages. According to the presented results, all the formulations of fermented dairy beverages are considered suitable for consumption. In RTIQ of Dairy Beverages (BRASIL, 2005), testing for presence of yeasts and molds is not required for fermented dairy beverages. The coliform results were similar to those reported by Oliveira et al. (2008) also showed similar results from his research on the development of formulation of araticum yogurt and study of sensory acceptance, wherein all the samples showed values below the limits established by the legislation.

Preference sensory analysis of the fermented dairy beverages prepared with and without araticum pulp

Preference-ordering tests of the samples by consumers showed no significant preferences $(p<0.05)$ between formulations of fermented dairy beverage according to the different percentages of pulp, i.e., all the samples were equally preferred by consumers (Table 6). These results can be attributed to acceptance, consumption, and knowledge of the araticum pulp and its derivatives by the consumers. Results from Oliveira et al. (2008) also verified that the different proportions of pulp did not affect the acceptance of the same. Similar behavior was observed for T4 (12.5\% of pulp) and T7 (20\%) formulations in preference tests (Table 6).

Oliveira et al. (2008), on evaluating the purchase intention of araticum yogurt found that more than 
$55 \%$ of yogurt consumers bought the product at concentrations of 12.5 and $25.0 \%$ of pulp. According to the authors, use of araticum pulp in yogurt production was a good choice for the industry because the product was acceptable to the consumers. According to Rodríguez et al. (2003), evaluation and determination of the acceptance and/ or preference, in the development process of new products, as well as after substitution of ingredients or process improvement, becomes indispensable.

Table 6. Average values of the sum of the orders of sensory preference among the samples of fermented dairy beverages prepared with different percentages of araticum pulp and whey concentrations.

\begin{tabular}{cccc}
\hline Treatments & Sum of orders & Treatments & Sum of orders \\
\hline T1 & $190 \mathrm{a}$ & T40 & $247 \mathrm{a}$ \\
T2 & $197 \mathrm{a}$ & T50 & $244 \mathrm{a}$ \\
T3 & $195 \mathrm{a}$ & T60 & $211 \mathrm{ab}$ \\
T4 & $212 \mathrm{a}$ & T70 & $224 \mathrm{ab}$ \\
T5 & $213 \mathrm{a}$ & $\mathrm{T} 80$ & $184 \mathrm{abc}$ \\
T6 & $197 \mathrm{a}$ & T90 & $167 \mathrm{bc}$ \\
T7 & $196 \mathrm{a}$ & $\mathrm{T} 100$ & $123 \mathrm{c}$ \\
\hline
\end{tabular}

Legend 1: T1: 5.0\%, T2: 7.5\%, T3: 10.0\%, T4: 12.5\%, T5: $15.0 \%, \mathrm{~T} 6: 17.5 \%$, and T7: $20.0 \%$ of pulp.

Legend 2: T40: 40\%, T50: 50\%, T60: 60\%, T70: 70\%, T80: 80\%, T90: 90\%, T100: 100\% of whey.

Sum of orders in the same column and with the same letters do not differ significantly from each other (regarding the preference), by Friedman test, $\mathrm{n}=50$ judges. The values correspond to the sum of orders.

The preference-ordering by consumers tests found no significant preferences $(p<0.05)$ between the formulations of fermented dairy beverages added with $40,50,60$, and $70 \%$ of whey, while the sample with $100 \%$ of whey was the least preferred one, as compared to the previous ones (Table 6). The formulations with $40,50,60$, and $70 \%$ of whey had, in terms of absolute values, the largest values of the sum of the orders. Caldeira et al. (2010) evaluated the physicochemical, sensory, and microbiological characteristics of dairy beverages prepared with buffalo milk and different levels of yogurt and whey. In their studies, only the samples formulated with 10 and $20 \%$ of whey did not significantly differ from each other $(p>0.05)$, being considered as the most preferred ones by the judges. All other combinations, consisting of 30,40 , and $50 \%$ of whey showed significant differences in preferences. Rocha (2008) evaluated the physicochemical, microbiological, and sensory characteristics of dairy beverages prepared with buffalo milk and different levels of yogurt and whey (in concentrations of $10,20,30,40$, and $50 \%$ ). They found that whey levels in dairy beverages influenced the sensory test preferences of the judges; according to the frequencies of total scores judged by the tasters, by means of the preference ordering test, the order of preference was $10 \%$ whey ( $29 \%$ of preference), $20 \%$ whey (26\% of preference), $30 \%$ whey (20\% of preference), $40 \%$ whey (16\% of preference), $50 \%$ whey ( $9 \%$ of preference).

\section{Conclusions}

The values of the parameters $\mathrm{pH}$, moisture, protein, total fiber, and ascorbic acid from araticum pulp without bleaching were superior from the ones from the bleached pulp. The parameters of ashes, lipids, total acidity, acidity in citric acid, total solids, total carbohydrates, and caloric values were higher in the samples of bleached araticum pulp, as compared to those in the samples of without bleaching araticum pulp. It was observed that both types of araticum pulp samples were fit for consumption. The bleaching process reduced the number of colonies of molds and yeasts, as compared to those in without bleaching pulp samples. 
Protein values in the formulations of fermented dairy beverage met the legislation, regardless of the concentrations of whey and pulp. Regarding the food safety, all the formulations of fermented dairy beverage were suitable for consumption. It was found that there was no significant preference between fermented dairy beverage formulations based on the different percentages of pulp, i.e., all samples were equally preferred by consumers. However, formulations with 40, 50, 60, and 70\% whey were preferred more than the formulation with $100 \%$ whey.

\section{Acknowledgements}

We would like to thank the Fundação de Amparo à Pesquisa do Estado de Goiás (FAPEG), for the Doctoral scholarship, the Food Research Center, and the Department of Food Engineering of the Goias Federal University for development of this research.

\section{References}

ALMEIDA, K. E.; BONASSI, I. A.; ROÇA, R. O. Características físicas e químicas de bebidas lácteas Fermentadas e preparadas com soro de leite. Ciência e Tecnologia de Alimentos, Campinas, v. 21, n. 2, p. 187192, 2001.

ALMEIDA, M. M. B.; SOUSA, P. H. M.; ARRIAGA, Â. M. C.; PRADO, G. M.; MAGALHÃES, C. E. C.; MAIA, G. A.; LEMOS, T. L. G. Bioactive compounds and antioxidant activity of fresh exotic fruits from northeastern Brazil. Food Research International, Barking, v. 44, n. 7, p. 2155-2159, 2011.

ALVES, C. C. C. Comportamento da Escherichia coli em queijo minas frescal elaborado com utilização de Lactobacillus acidophifilus e de acidificação direta com ácido lático. 2010. Dissertação (Mestrado em Medicina Veterinária) - Universidade Federal Fluminense, Niterói.

ANDRADE, E. H. P. Qualidade físico-química, microbiológica e detecção de soro lácteo por cromatografia líquida de alta eficiência em bebidas lácteas fermentadas. 2010. Dissertação (Mestrado em Ciência Animal) - Universidade Federal de Minas Gerais, Escola de Veterinária, Belo Horizonte.
ANSELMO, G. C. S.; MATA, M. E. R. M. C.; ARRUDA, P. C.; SOUSA, M. C. Determinação da higroscopicidade do cajá em pó por meio da secagem por atomização. Revista de Biologia e Ciências da Terra, Campina Grande, v. 6, n. 2, p. 58-65, 2006.

ANTUNES, A. E. C.; CAZETTO, T. F.; BOLINI, H. M. A. Skim yogurts added by whey protein concentrate: texture profile, syneresis and sensorial analysis. Alimentos $e$ Nutrição, Marília, v. 15, n. 2, p. 105-114, 2004.

BELLARDE, F. B. Elaboração de doce de leite pastoso com substituição parcial de sólidos do leite por concentrado proteico do soro. Revista Uniara, Araraquara, v. 1, n. 17-18, p. 249-255, 2006.

BORGES, K. C.; MEDEIROS, A. C. L.; CORREIA, R. T. P. Iogurte de leite de búfala sabor cajá (Spondias lutea L.): caracterização físico-química e aceitação sensorial entre indivíduos de 11 a 16 anos. Alimentação e Nutrição, São Paulo, v. 20, n. 2, p. 295-300, 2009.

BRASIL. Ministério da Agricultura, Pecuária e do Abastecimento. Instrução Normativa $n^{\circ} 46$, de 23 de outubro de 2007. Aprova o Regulamento Técnico de Identidade e Qualidade de Leites Fermentados. Diário Oficial [da] República Federativa do Brasil, Brasília, 24 out. 2007, Seção 1, p. 5.

. Secretaria de Inspeção de Produto Animal. Instrução Normativa $\mathrm{n}^{\mathrm{o}}$ 68, de 12 de dezembro de 2006. Oficializa os Métodos Analíticos Oficiais FísicoQuímicos, para Controle de Leite e Produtos Lácteos, em conformidade com o anexo desta Instrução Normativa, determinando que sejam utilizados nos Laboratórios Nacionais Agropecuários. Diário Oficial [da] República Federativa do Brasil, Brasília, 14 dez. 2006, Seção 1, p. 8.

Instrução Normativa, $\mathrm{n}^{\circ} 1$ de 7 de

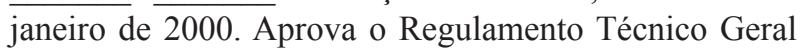
para Fixação dos Padrões de Identidade e Qualidade para Polpa de Fruta. Diário Oficial [da] União, Brasília, 10 jan. 2000, Seção 1, p. 54.

- Secretaria de Inspeção de Produto Animal. Instrução Normativa no 62 de 26 de agosto de 2003. Oficializa os métodos analíticos oficiais para análises microbiológicas para controle de produtos de origem animal e água. Diário Oficial [da] República Federativa do Brasil, Brasília, 18 set. 2003, Seção 1, p. 14.

Secretaria de Inspeção de Produto Animal. Instrução Normativa $\mathrm{n}^{\circ} 16$, de 23 de agosto de 2005. Aprova o Regulamento Técnico de Identidade e Qualidade de Bebidas Lácteas. Diário Oficial [da] República Federativa do Brasil, Brasília, 24 ago. 2005, Seção 1, p. 7. 
Ministério da Saúde. Secretaria de Vigilância

Sanitária. Resolução $\mathrm{n}^{\circ} 12$, de 02 de janeiro de 2001. Aprova o Regulamento Técnico sobre padrões microbiológicos para alimentos. Diário Oficial [da] República Federativa do Brasil, Brasília, 10 jan. 2001, Seção 1, p. 46-53.

BUENO, S. M.; GRACIANO, R. A. S.; FERNANDES, E. C. B.; GARCIA-CRUZ, C. H. Avaliação da qualidade de polpas de frutas congeladas. Revista Instituto Adolfo Lutz, São Paulo, v. 62, n. 2, p. 121-126, 2002.

CALDEIRA, L. A.; FERRÃO, S. P. B.; FERNANDES, S. A. A.; MAGNAVITA, A. P. A.; SANTOS, T. D. R. Desenvolvimento de bebida láctea sabor morango utilizando diferentes níveis de iogurte e soro lácteo obtidos com leite de búfala. Ciência Rural, Santa Maria, v. 40, n. 10, p. 2193-2198, 2010.

CAPITANI, C. D.; PACHECO, M. T. B.; GUMERATO, H. F.; VITALI, A.; SCHMIDT, F. L. Recuperação de proteínas do soro de leite por meio de coacervação com polissacarídeo. Pesquisa Agropecuária Brasileira, Rio de Janeiro, v. 40, n. 11, p. 1123-1128, 2005.

CASTRO, F. P.; CUNHA, T. M.; OGLIARI, P. J.; TEÓFILO, R. F.; FERREIRA, M. M. C.; PRUDÊNCIO, E. S. Influence of different content of cheese whey and oligofructose on the properties of fermented lactic beverages: Study using response surface methodology. LWT-Food Science and Technology, London, v. 42, n. 1, p. 993-997, 2009.

CECCHI, H. M. Fundamentos teóricos e práticos em análise de alimentos. 2. ed. rev. Campinas: Editora da UNICAMP, 2007. 208 p.

CIABOTTI, S.; BARCELOS, M. F. P.; CIRILLO, M. A.; PINHEIRO, A. C. M. Propriedades tecnológicas e sensoriais de produto similar ao tofu obtido pela adição de soro de leite ao extrato de soja. Ciência e Tecnologia de Alimentos, Campinas, v. 29, n. 2, p. 346-353, 2009.

CLERICI, M. T. P. S.; CARVALHO-SILVA, L. B. Nutritional bioactive compounds and technological aspects of minor fruits grown in Brazil. Food Research International, Barking, v. 44, n. 7, p. 1658-1670, 2011.

COSTA, N. M. B.; SILVA, M. R.; FERREIRA, C. L. F.; FRANCESCHINI, S. C. C. Fortificação do soro de queijo com ferro. Revista Médica de Minas Gerais, Belo Horizonte, v. 17, n. 1-2, p. 51-54, 2007. Suplemento.

CUNHA, T. M.; CASTRO, F. P.; BARRETO, P. L. M.; BENEDET, H. D.; PRUDÊNCIO, E. S. Avaliação físicoquímica, microbiológica e reológica de bebida láctea e leite fermentado adicionados de probióticos. Semina: Ciências Agrárias, Londrina, v. 29, n. 1, p. 103-116, 2008.
DOWNES, F. P.; ITO, K. (Ed.). Compendium of methods for the microbiological examination of foods. $4^{\text {th }}$. ed. Washington: American Public Health Association (APHA), 2001. $676 \mathrm{p}$.

FERCHICHI, M.; CRABBE, E.; GIL, G. H.; HINTZ, W.; ALMADIDY, A. Influence of initial pH on hydrogen production from cheese whey. Journal of Biotechnology, Amsterdam, v. 120, n. 4, p. 402-409, 2005.

GHALY, A. E.; KAMAL, M. A. Submerged yeast fermentation of acid cheese whey for protein production and pollution potential reduction. Water Research, New York, v. 38, n. 3, p. 631-644, 2004.

HOFMEISTER, L. C.; SOUZA, J. A. R.; PETRUS, J. C. C.; LAURINDO, J. B. Salga de queijo tipo minas por impregnação a vácuo. Ciência e Tecnologia de Alimentos, Campinas, v. 25, n. 3, p. 487-494, 2005.

INSTITUTO ADOLFO LUTZ - IAL. Métodos físicoquímicos para análise de alimentos. ZENEBON, O.; PASCUET, N. S.; TIGLEA, P. (Coord.). 4. ed. São Paulo: Instituto Adolfo Lutz, 2008. 1020p.

JAEKEL, L. Z.; RODRIGUES, R. S.; SILVA, A. P. Avaliação físico-química e sensorial de bebidas com diferentes proporções de extratos de soja e de arroz. Ciência e Tecnologia de Alimentos, Campinas, v. 30, n. 2, p. 342-348, 2010.

LIRA, H. L.; SILVA, M. C. D.; VASCONCELOS, M. R. S.; LIRA, H. L.; LOPEZ, A. M. Q. Microfiltração do soro de leite de búfala utilizando membranas cerâmicas como alternativa ao processo de pasteurização. Ciência e Tecnologia de Alimentos, Campinas, v. 29, n. 1, p. 33-37, 2009.

LOURES, M. M. R.; MINIM, V. P. R.; CERESINO, E. B.; CARNEIRO, R. C.; MINIM, L. A. Análise descritiva por ordenação na caracterização sensorial de iogurte diet sabor morango enriquecido com concentrado protéico do soro. Semina: Ciências Agrárias, Londrina, v. 31, n. 3, p. 661-668, 2010.

LUZIA, D. M. M.; JORGE, N. Bioactive substance contents and antioxidant capacity of the lipid fraction of Annona crassiflora Mart. Seeds. Industrial Crops and Products, Oxford, v. 42, n. 1, p. 231-235, 2013.

MARTINS, S. C. S. G.; ROCHA JÚNIOR, V. R.; CALDEIRA, L. A.; REIS, S. T.; BARROS, I. C.; OLIVEIRA, J. A.; SANTOS, J. F.; SILVA, G. W. V. Rendimento, composição e análise sensorial do queijo minas frescal fabricado com leite de vacas mestiças alimentadas com diferentes volumosos. Revista Brasileira de Zootecnia, Viçosa, MG, v. 41, n. 4, p. 9931003, 2012. 
MENEZES, A. C. S. Desenvolvimento de bebida láctea fermentada à base de soro de leite e polpa de cajá (Spondias mombin L.) com potencial atividade probiótica. 2011. Dissertação (Mestrado em Ciência e Tecnologia de Alimentos) - Universidade Federal Rural de Pernambuco, Recife.

MESQUITA, M. A. M.; NAVES, R. V.; SOUZA, E. R. B.; BERNARDES, T. G.; SILVA, L. B. Caracterização de ambientes com alta ocorrência natural de araticum (Annona crassiflora Mart.) no estado de Goiás. Revista Brasileira de Fruticultura, Jaboticabal, v. 29, n. 1, p. 1519, 2007.

MINIM, V. P. R. Análise sensorial: estudos com consumidores. Viçosa, MG: Ed. UFV, 2010. 308 p.

MONTANUCI, F. D; GARCIA, S.; PRUDÊNCIO, S. H. Caracterização sensorial e aceitação de kefir adoçado integral e desnatado com inulina. Brazilian Journal of Food Technology, Campinas, Preprint Series, n. 10, 2011. Separata: Brazilian Journal of Foof Technology, $6^{\circ}$ SENSIBER, 19-21 de agosto, p. 79-90, 2010. Disponível em: <http://www.ital.sp.gov.br/bj/artigos/especiais/2011/ bjft_v14ne01_pp/10_bjft_v14ne01_140111_pp.pdf>. Acesso em: 13 set. 2016 .

MOREIRA, R. W. M.; MADRONA, G. S.; BRANCO, I. G.; BERGAMASCO, R.; PEREIRA, N. C. Avaliação sensorial e reológica de uma bebida achocolatada elaborada a partir de extrato hidrossolúvel de soja e soro de queijo. Acta Scientiarum Technology, Maringá, v. 32, n. 4, p. 435-438, 2010.

OLIVEIRA, K. A. M.; RIBEIRO, L. S.; OLIVEIRA, G. V.; PEREIRA, J. M. A. T. K.; MENDONÇA, R. C. S.; ASSUMPÇÃO, C. F. Desenvolvimento de formulação de iogurte de araticum e estudo da aceitação sensorial. Alimentos e Nutrição, Araraquara, v. 19, n. 3, p. 277-281, 2008.

OLIVEIRA, V. B.; YAMADA, L. T.; FAGG, C. W.; BRANDÃO, M. G. L. Native foods from Brazilian biodiversity as a source of bioactive compounds. Food Research International, Barking, v. 48, n. 1, p. 170-179, 2012.

OLIVEIRA, V. M.; CORTEZ, M. A. S.; FREITAS, M. Q.; FRANCO, R. M. Avaliação sensorial de bebida láctea fermentada com diferentes concentrações de soro de queijo, enriquecida com ferro. Revista Brasileira de Ciência Veterinária, Niterói, v. 13, n. 2, p. 67-70, 2006.

PANESAR, P. S.; KENNEDY, J. F.; GANDHI, D. N.; BUNKO, K. Bioutilisation of whey for lactic acid production. Food Chemistry, London, v. 105, n. 1, p. 1-14, 2007.
PFLANZER, S. B.; CRUZ, A. G.; HATANAKA, C. L.; MAMEDE, P. L.; CADENA, R.; FARIA, J. A. F.; SILVA, M. A. A. P. Perfil sensorial e aceitação de bebida láctea achocolatada. Ciência e Tecnologia de Alimentos, Campinas, v. 30, n. 2, p. 391-398, 2010.

PORTO, L. M.; SANTOS, R. C.; MIRANDA, T. L. S. Determinação das melhores condições operacionais do processo de produção da ricota. Boletim do Centro de Pesquisa e Processamento de Alimentos, Curitiba, v. 23, n. 1, p. 173-182, 2005.

R DEVELOPMENT CORE TEAM. $R$ : a language and environment for statistical computing, reference index version 2.11.1 (2010-05-31). Copyright (C) 2010. Vienna: The R Foundation for Statistical Computing, Austria, 2010.

RODRÍGUEZ, M. B. S.; MEGÍAS, S. M.; BAENA, B. M. Alimentos funcionales y nutrición óptima. ¿Cerca o lejos? Revista Española de Salud Pública, Madrid, v. 77, n. 3, p. 317-331, 2003

ROCHA, L. A. C. Qualidade do leite de búfala e desenvolvimento de bebida láctea com diferentes níveis de iogurte e soro de queijo. 2008. Dissertação (Mestrado em Engenharia de Alimentos) - Universidade Estadual do Sudoeste da Bahia, Itapetinga.

SANTOS, C. T.; COSTA, A. R.; FONTAN, G. C. R.; FONTAN, R. C. I.; BONOMO, R. C. F. influência da concentração de soro na aceitação sensorial de bebida láctea fermentada com polpa de manga. Alimentos $e$ Nutrição, Araraquara, v. 19, n. 1, p. 55-60, 2008.

SILVA, M. R.; LACERDA, D. B. C. L.; SANTOS, G. G.; MARTINS, M. O. M. Caracterização química de frutos nativos do cerrado. Ciência Rural, Santa Maria, v. 38, n. 6, p. 1790-1793, 2008.

SOARES JUNIOR, M. S.; BASSINELLO, P. Z.; CALIARI, M.; VELASCOIV, P.; REIS, R. C.; CARVALHO, W. T. Bebidas saborizadas obtidas de extratos de quirera de arroz, de arroz integral e de soja. Ciência e Agrotecnologia, Lavras, v. 34, n. 2, p. 407-413, 2010.

SOARES, D. S.; FAI, A. E. C.; OLIVEIRA, A. M.; PIRES, E. M. F.; STAMFORD, T. L. M. Aproveitamento de soro de queijo para produção de iogurte probiótico. Arquivo Brasileiro de Medicina Veterinária e Zootecnia, Belo Horizonte, v. 63, n. 4, p. 996-1002, 2011.

SOUZA, V. R.; PEREIRA, P. A. P.; QUEIROZ, F.; BORGES, S. V.; CARNEIRO, J. D. S. Determination of bioactive compounds, antioxidant activity and chemical composition of cerrado brazilian fruits. Food Chemistry, London, v. 134, n. 1, p. 381-386, 2012. 
TABELA BRASILEIRA DE COMPOSIÇÃO DE ALIMENTOS - TACO. NEPA-UNICAMP. 4. ed. rev. e ampl. Campinas: Núcleo de Estudos e Pesquisas em Alimentação (NEPA); Universidade Estadual de Campinas (UNICAMP), 2011. 161 p.

THAMER, K. G.; PENNA, A. L. B. Caracterização de bebidas lácteas funcionais fermentadas por probióticos e acrescidas de prebiótico. Ciência e Tecnologia de Alimentos, Campinas, v. 26, n. 3, p. 589-595, 2006.

ZULUETA, A.; ESTEVE, M. J.; FRASQUET, I.; FRÍGOLA, A. Vitamin C, vitamin A, phenolic compounds and total antioxidant capacity of new fruit juice and skim milk mixture beverages marketed in Spain. Food Chemistry, London, v. 103, n. 4, p. 1365-1374, 2007. 